\title{
Импортозамещающая
}

\section{геофизическая аппаратура}

\section{производства ФГУП «ВНИИА»}

Нач. отдела ФГУП «ВНИИА»

Хомяков Александр Сергеевич

17.04.2019

г. Москва 


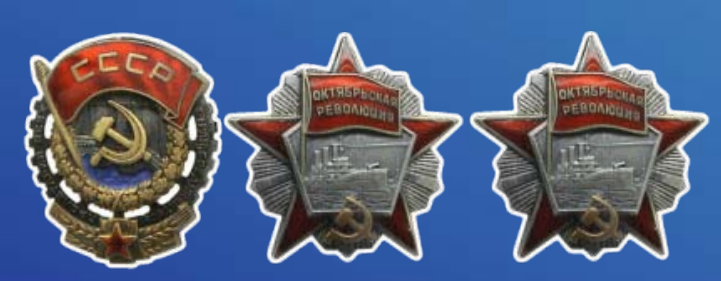

\section{Всероссийский НИИ автоматики им. Н.Л.Духова (ВНИИА)}

Основан в соответствии с Постановлением СМ СССР № 825-354 от 5 мая 1954 г., входит в состав ядерного оружейного комплекса Государственной корпорации по атомной энергии «Росатом».

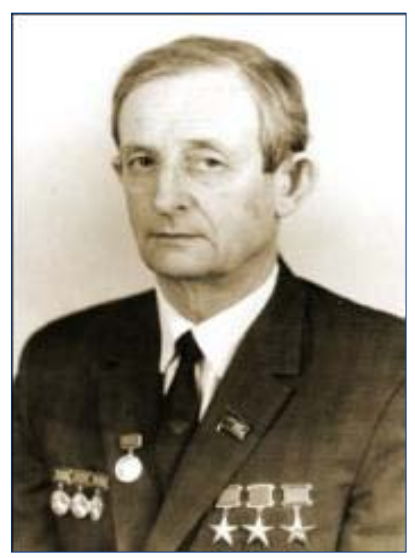

Харитон Юлий Борисович

трижды Герой

Социалистического Труда, академик, инициатор создания ВНИИА

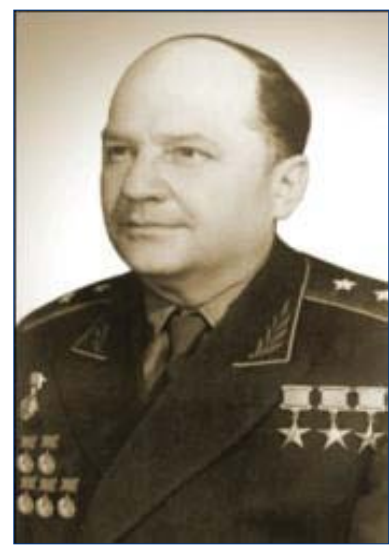

Духов

Николай Леонидович

трижды Герой

Социалистического Труда, первый директор, научный руководитель, главный конструктор

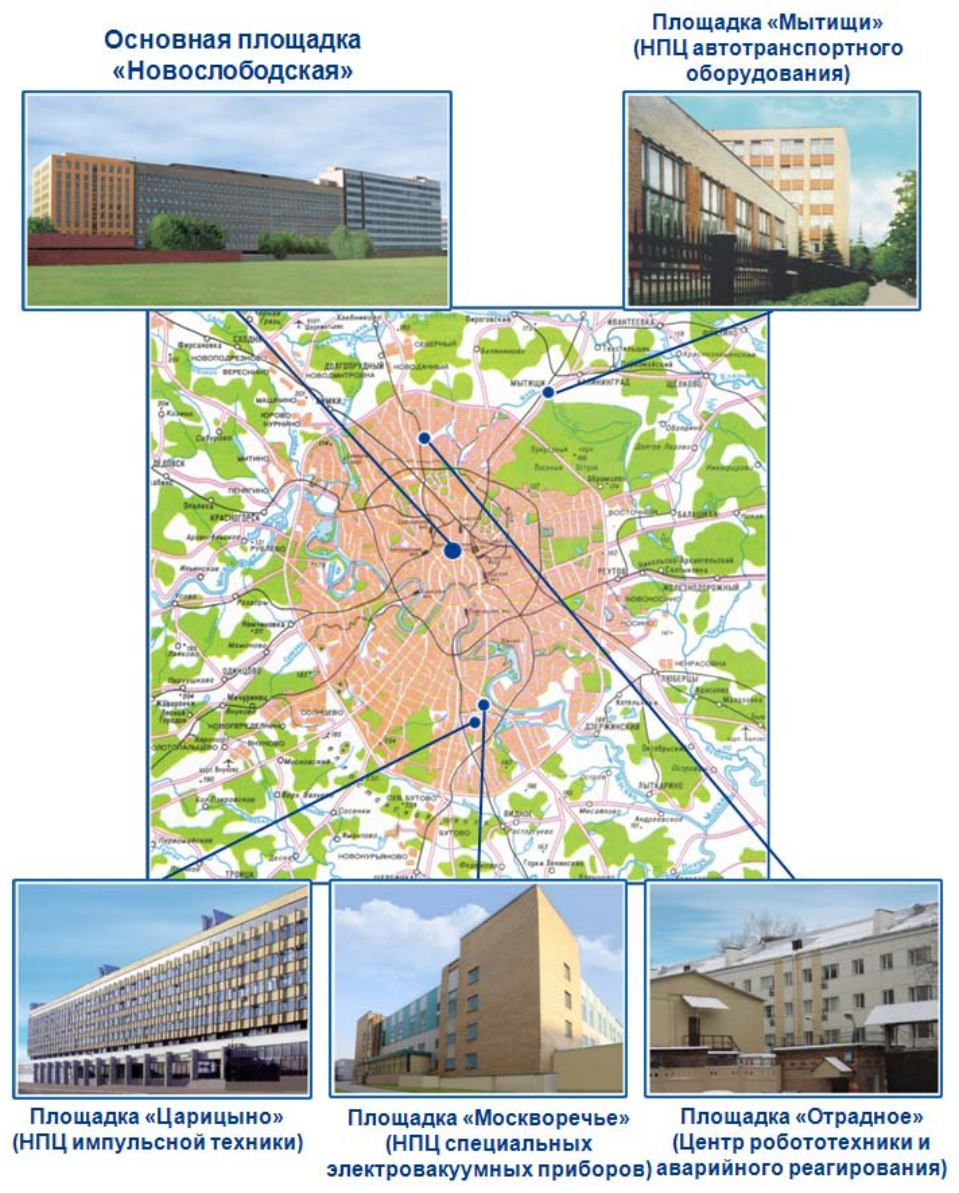




\section{Участие в Программе импортозамещения в ТЭК}

- В рамках Программы импортозамещения в топливно-энергетическом комплексе подписаны Соглашения о разработке перспективной геофизической аппаратуры с крупнейшими недропользователями России.
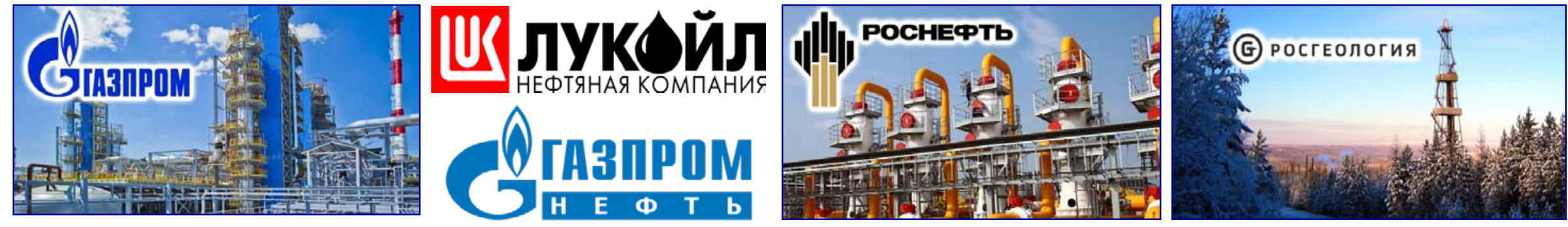

Преимущества

- Реализация методов радиоактивного каротажа на современном уровне

- Повышение радиационной и экологической безопасности при транспортировке, эксплуатации и хранении аппаратуры

- Повышение коэффициента извлечения нефти

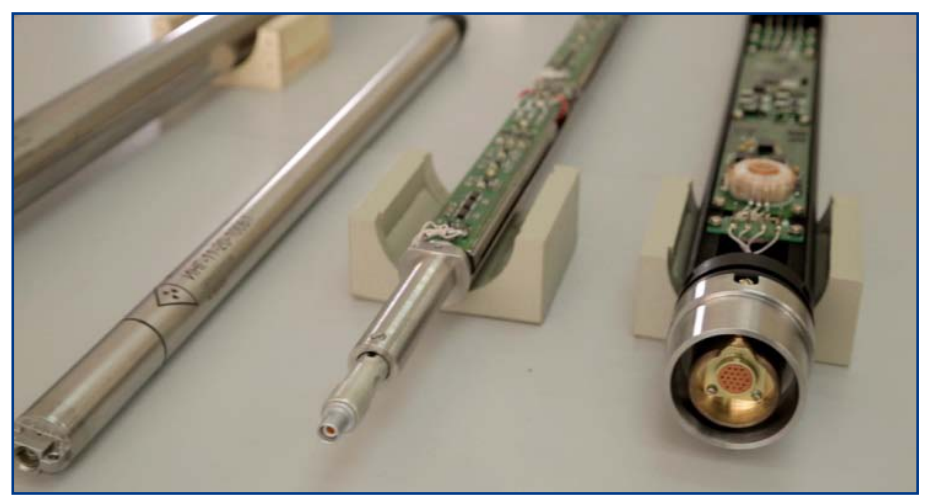

- Импортозамещение 


\section{Нейтронные генераторы и аппаратурные комплексы на их основе}

- $\quad$ Выпускаются для различных областей применения, включая:

- $\quad$ каротаж нефтегазовых и урановых скважин

- контроль технологических процессов промышленных производств, сертификация продукции

- обнаружение и идентификация ядерных материалов, взрывчатых и отравляющих веществ

- нейтронная терапия

- нейтронная радиография и томография

- научные исследования, в том числе исследования планет Солнечной системы
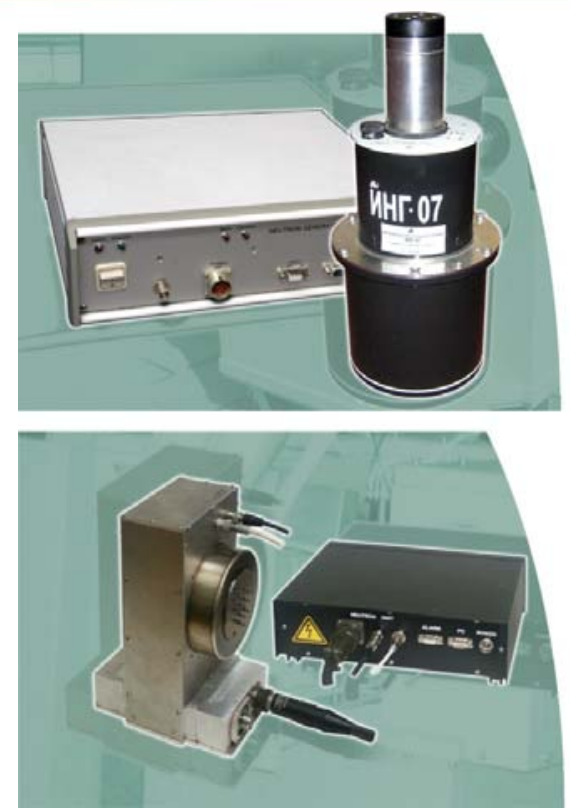

\section{Нейтронные генераторы разработки ВНИИА имеют уникальные характеристики:}

- нейтронный выход до $10^{11}$ нейтр./с

- длительность импульсов излучения от 0,01 мкс до 10 мс

- частоты повторения импульсов от одиночных до 10 кГц

Более 4000 нейтронных генераторов и около 500 аппаратурных комплексов поставлены потребителям в России, США, Великобритании, Германии, Китае, Японии, Италии, Израиля, 


\section{Аппаратура импульсного}

\section{нейтронного гамма-спектрометрического каротажа} АИНК-ПЛ 


\section{Физические основы импульсного нейтронного гамма- спектрометрического каротажа}

Метод ИНГК-С основан на облучении горной породы быстрыми нейтронами (14 МэВ) и регистрации вторичного гамма-излучения, возникающего в результате взаимодействия нейтронов с ядрами горных пород.
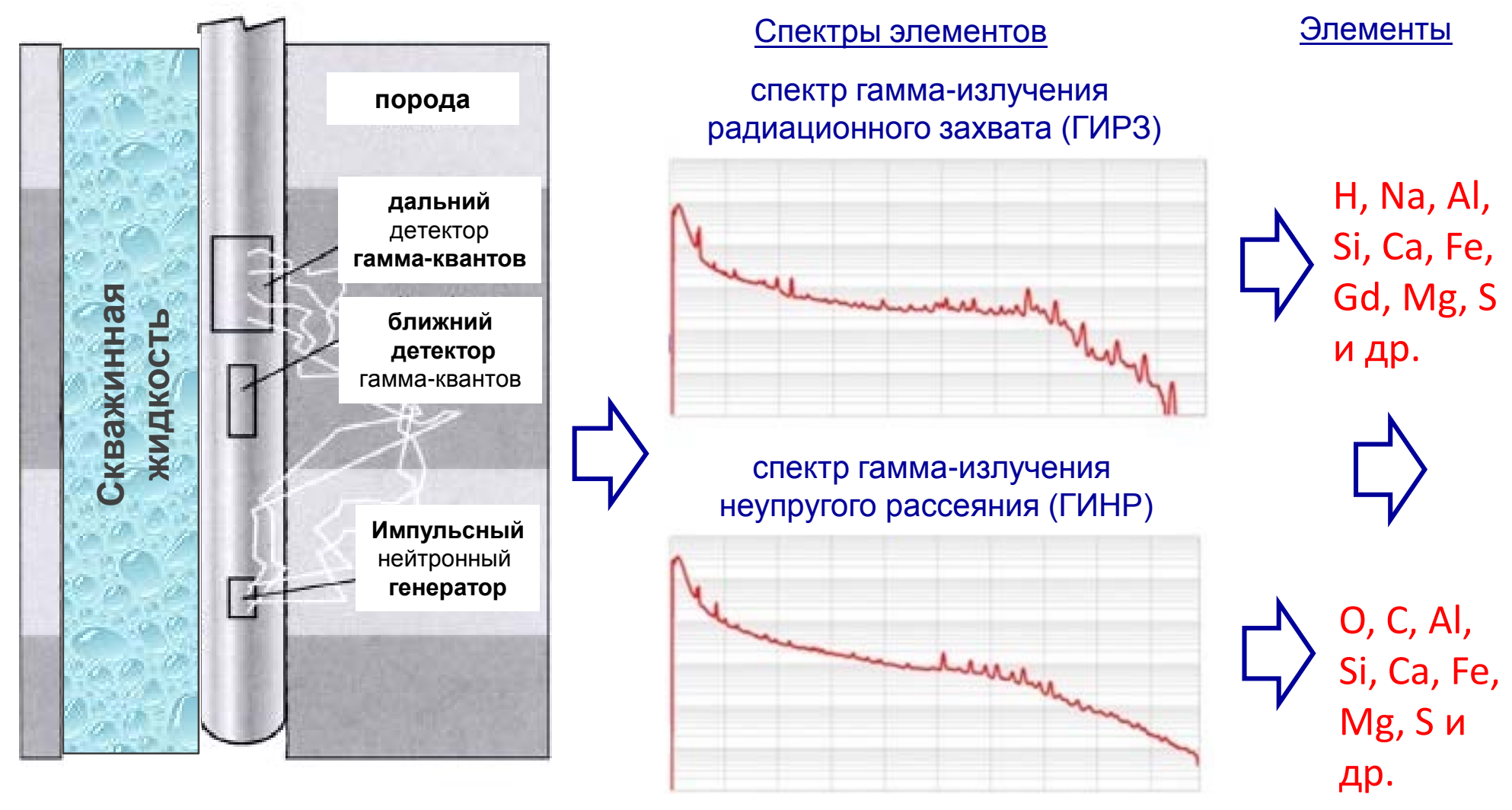

Минералогическая модель пласта

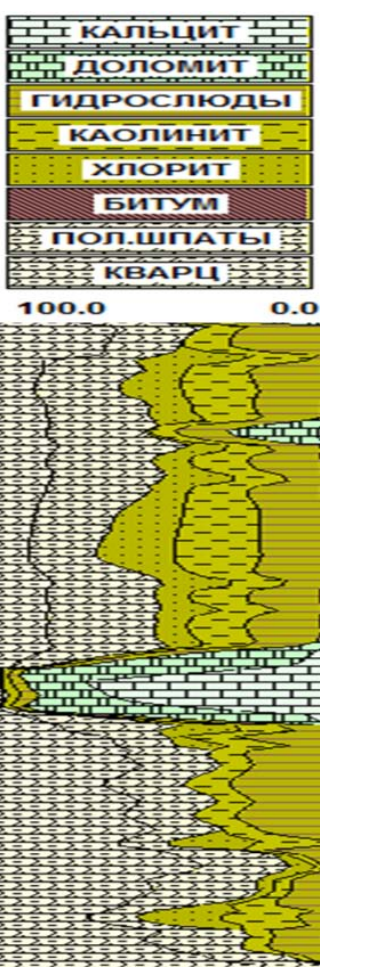




\section{Аппаратура импульсного нейтронного гамма- спектрометрического каротажа АИНК-ГЛ}

ГK-89C

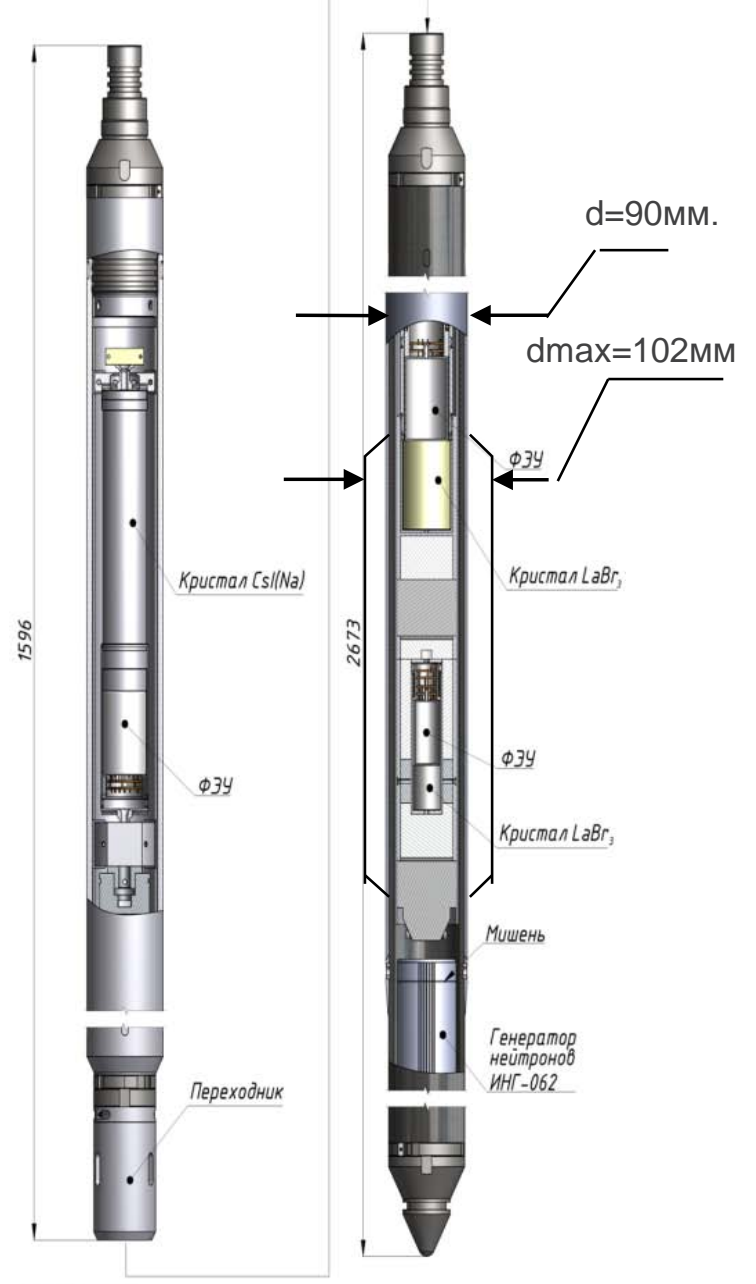

\section{Назначение:}

- Определение элементного состава пород и текущей нефтегазонасыщенности коллекторов независимо от минерализации

\section{Решаемые задачи:}

- Определение элементного и минералогического состава горных пород

- Определение минералогической плотности горных пород;

- Определение пористости горных пород

- Определения насыщенности коллекторов

- Определение положения флюидальных контактов

\section{Особенности:}

- Проведение исследований в обсаженных и необсаженных скважинах диаметром от 120 до 245 мм

- Применение управляемого импульсного нейтронного генератора

- Применение метода ГK-C (U, Th, K)

- Применение уникального сцинтилляционного детектора гамма квантов - бромид лантана (LaBr3) 


\section{Основные технические характеристики аппаратурного комплекса АИНК-ПЛ}

\section{Технические характеристики}

\begin{tabular}{l|c|}
\hline Диапазон определения плотности, г/см³ & $1,7-3,0$ \\
\hline Диапазон определения водородосодержания, \% & $1-40$
\end{tabular}

Определяемые элементы

Диапазон определения макроскопического сечения поглощения тепловых нейтронов, $\Sigma \mathrm{a} * 10^{-3} \mathrm{~cm}^{-1}$

Поток генератора нейтронов, н/с

Диапазон определения массовых долей ЕРЭ:

для калия - K, \%

для тория - Th и урана - U(Ra), ppm

Длина, мм

Диаметр прибора, мм

Диаметр максимальный в области борной защиты, мм

Скорость записи, м/ч

Максимальная температура, ${ }^{0} \mathrm{C}$

Максимальное давление, МПа

Детектор гамма-квантов
Ca, Mg, Si, Al, O, H,Fe и др.

$$
7,4-22,2
$$

$2,5^{*} 10^{8}$

0,3-20

$1 \div 200$

4300

$73 / 90$

$76 / 102$

$36 / 72$

120

80

$\mathrm{LaBr} 3$ 


\section{Сопоставление АИНК-ПЛ с лучшим аналогом Litho Scanner}

\section{АИНК-ПЛ}

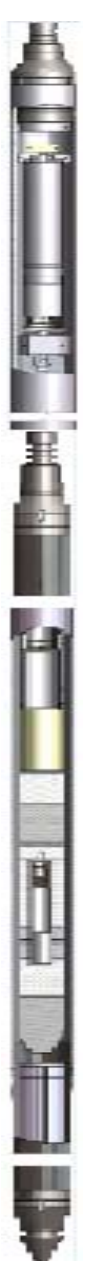

\begin{tabular}{|c|c|c|}
\hline АИНК-ПЛ & Характеристики & $\begin{array}{l}\text { Litho Scanner } \\
\text { (Schlumberger) }\end{array}$ \\
\hline $\begin{array}{c}\mathrm{Fe}, \mathrm{Si}, \mathrm{Mg}, \mathrm{Ca}, \\
\mathrm{Al}, \mathrm{Cl}, \mathrm{O}, \mathrm{C} \text { и др. }\end{array}$ & $\begin{array}{c}\text { Определяемые } \\
\text { элементы породы }\end{array}$ & $\begin{array}{c}\mathrm{Fe}, \mathrm{Si}, \mathrm{Mg}, \mathrm{Ca}, \mathrm{Al}, \\
\text { Cl, O, С и др. }\end{array}$ \\
\hline 4,3 & Lприбора, м & 4,27 \\
\hline 102 & Dmax, MM & 114 \\
\hline 120 & Масса прибора, кг & 166 \\
\hline свободное & $\begin{array}{c}\text { Расположение в } \\
\text { скважине }\end{array}$ & прижимное \\
\hline LaBr3 & $\begin{array}{c}\text { Применяемый } \\
\text { детектор }\end{array}$ & LaBr3 \\
\hline 2 & Кол-во детекторов & 1 \\
\hline ИНГК-С, ГК-С & $\begin{array}{c}\text { Применяемые } \\
\text { методы }\end{array}$ & ИНГК-С \\
\hline
\end{tabular}

\section{Litho Scanner}

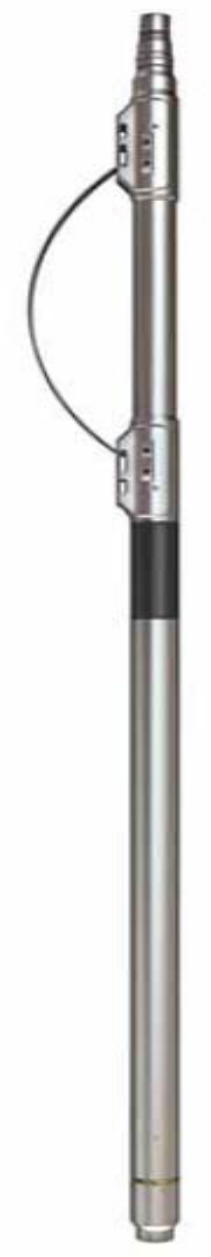




\section{ОПИ аппаратуры АИНК-ПЛЛ}

\section{в части определения нефтенасыщенности и поиска пропущенных залежей}

\section{Отложения верхнего карбона. Корреляция по кровле залежи}

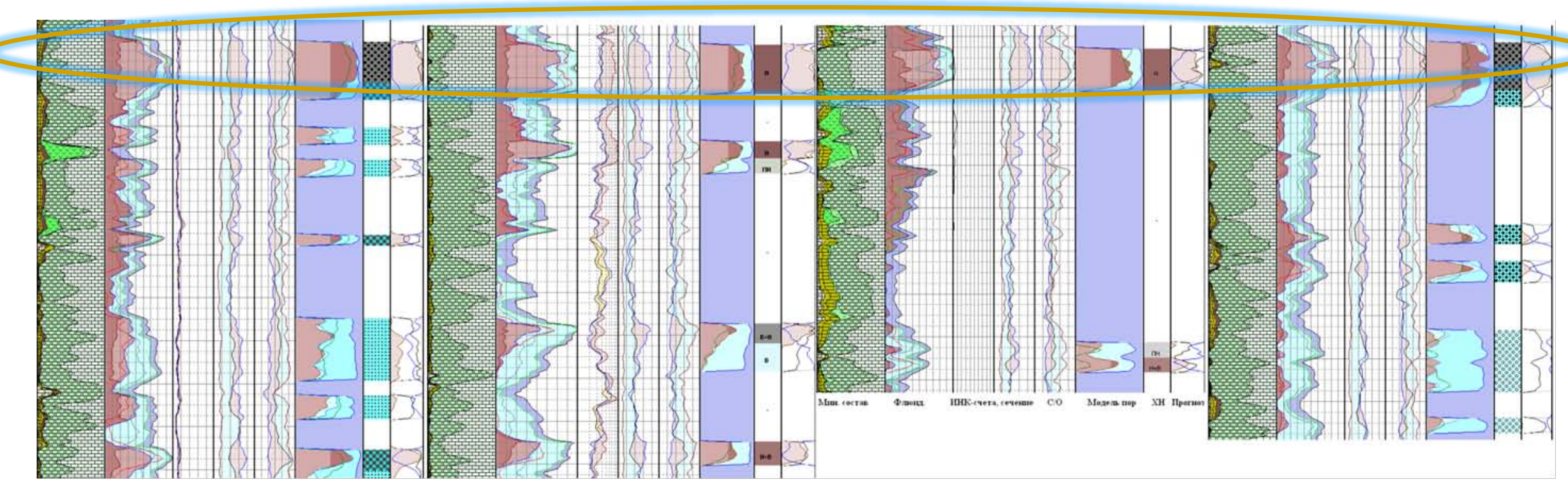

\begin{tabular}{|c|c|c|}
\hline \multicolumn{3}{|c|}{ Текущий режим работы } \\
\hline Жидкость, м3/сут. & Нефть, т./сут. & \% обв. \\
\hline 41 & 22 & 42 \\
\hline 22 & 18 & 9 \\
\hline 65 & 38 & 37 \\
\hline 75 & 39 & 44 \\
\hline
\end{tabular}




\section{ОПИ аппаратуры АИНК-ГЛ}

\section{в части определения минералогического состава}

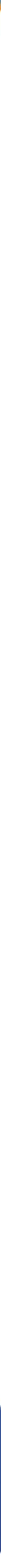




\section{Опытно-промышленные испытания АИНК-ПЛ}

\section{Комплекс АИНК-ПЛ позволяет определять:}

>объемную плотность горных пород

$>$ концентрации породо- и фрлюидообразующих химических элементов и делать выводы по минералогическому составу горных пород

$>$ интегральную и дифреренцированную естественную гамма-активность

$>$ текущую нефртегазонасыщенность

Повышает:

Руровень радиационной безопасности Р уровень геологчческих знаний о минералогчческом строении разреза (локальные реперы, детальная корреляция, условии осадконакопления и т.п)

В части определения нефтенасыщенности горных пород (в режиме С/О каротажа) результаты согласуются с данными открытого ствола, недостатков метода не выявлено

В части определения элементного и минералогического состава горных породы (режим литокаротаж) требуется доработка АИНК-ПЛ в части методики обработки данных. Методика будет настраиваться по результатам исследования керна 


\section{Система многопараметрических}

\section{исследований скважин в процессе бурения}

\section{СМИС-172-Б}




\section{Система многопараметрических исследований скважин в процессе бурения СМИС-172-Б}

\begin{abstract}
Назначение: направленного бурения, а также исследования геофизических параметров скважин непосредственно в процессе бурения
\end{abstract}

\section{Комплекс позволяет определять:}

\section{$>$ Плотность}

П Пористость

Концентрации основных элементов

$>$ Азимутальный, зенитный угол

- Естественную гамма-активность

Удельное электрическое сопротивление

\section{Особенности:}

Применение управляемого импульсного нейтронного генератора

Определение компонентного состава порового флюида независимо от минерализации

\begin{tabular}{l|c}
\multicolumn{1}{c|}{ Параметр } & Значение \\
\hline Максимальная температура, ${ }^{\circ}$ C: & 120 \\
\hline Максимальное гидростатическое давление, МПа & не менее 80 \\
\hline Наружный диаметр модулей, мм & 172 \\
\hline Диаметр модулей «струны», мм, не более & 48 \\
\hline Предельные нагрузки на комплекс: & \\
\hline - допустимый крутящий момент, кНм & 30 \\
\hline - допустимое растягивающее усилие, кН & 1250 \\
\hline - допустимое сжимающее усилие, кН & 1000 \\
\hline Максимальная интенсивность набора кривизны & $5^{\circ}$ на 10 м \\
\hline Время работы в автономном режиме, час, не & 200 \\
\hline менее &
\end{tabular}

литиевые батареи

250

(14-23) 


\section{Система многопараметрических исследований скважин в процессе бурения СМИС-172-Б}

\section{МУП-172-Б: Модуль управления пульсатором}

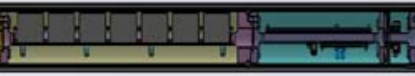

ИНгК-172-Б: Модуль ИНгКС

(2) МП-172-Б: Модуль питания ИНГКС (2шт.)

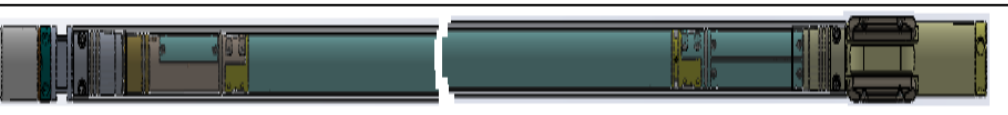

МПГ-172-Б: Модуль питания

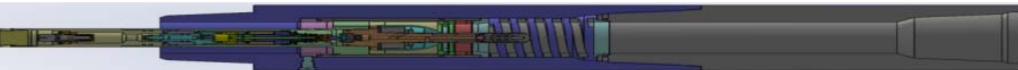

\section{МПИ-172-Б: Модуль памяти и измерения}

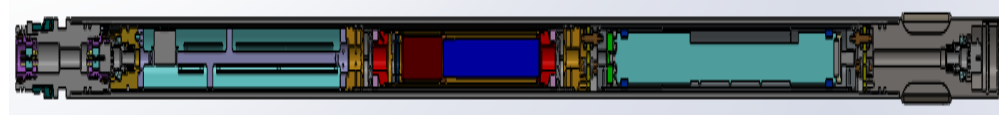

ВИКПБ-172-Б: Модуль высокочастотного индукционного каротажа в процессе бурения
Передача информации по гидравлическому каналу связи со скоростью 1 бит/сек, регистрация давления

Регистрирует: спектры ГИРЗ, ГИНР (в память), плотность (он-лайн ), пористость (он-лайн)

Обеспечивает питание модуля ИНГК

Обеспечивает питание комплекса литиевой батареей напряжением 18B x 48 А /ч. С помощью управления насосами по циклограмме позволяет обеспечить работу комплекса в течении 200 часов.

Обеспечивает управление режимами работы всех модулей, сохранение результатов измерений в память, регистрирует ГК (он-лайн) и инклинометрия (он-лайн)

Обеспечивает измерение УЭС с помощью 6 разноглубинных зондов (он-лайн) 


\section{ОПИ СМИС-172-Б Западная Сибирь}

\section{Параметры скважины}

\begin{tabular}{|l|c|}
\hline Диаметр долота, мм & 220.9 \\
\hline Интервал исследования, м & 2660-3152
\end{tabular}

\section{Результаты интерпретации}

\begin{tabular}{|c|c|c|c|c|}
\hline № & Кровля,м & Подошва, $\mathrm{M}$ & Кпоб, \% & Кн-ЯФМ, \% \\
\hline 1 & 2661.8 & 2662.6 & 21.7 & 17 \\
\hline 2 & 2662.6 & 2663.2 & 22.5 & 34 \\
\hline 3 & 2666.2 & 2666.8 & 21.2 & 37 \\
\hline 4 & 2666.8 & 2667.8 & 23.6 & 20 \\
\hline
\end{tabular}

\section{Модель твердой составляющей породы:}

$\begin{array}{ll}\text { - песчаник } & \text { - алевролит } \\ \text {-аргиллит } & \text { - глина } \\ \text {-карбонаты } & \text { - баженит }\end{array}$

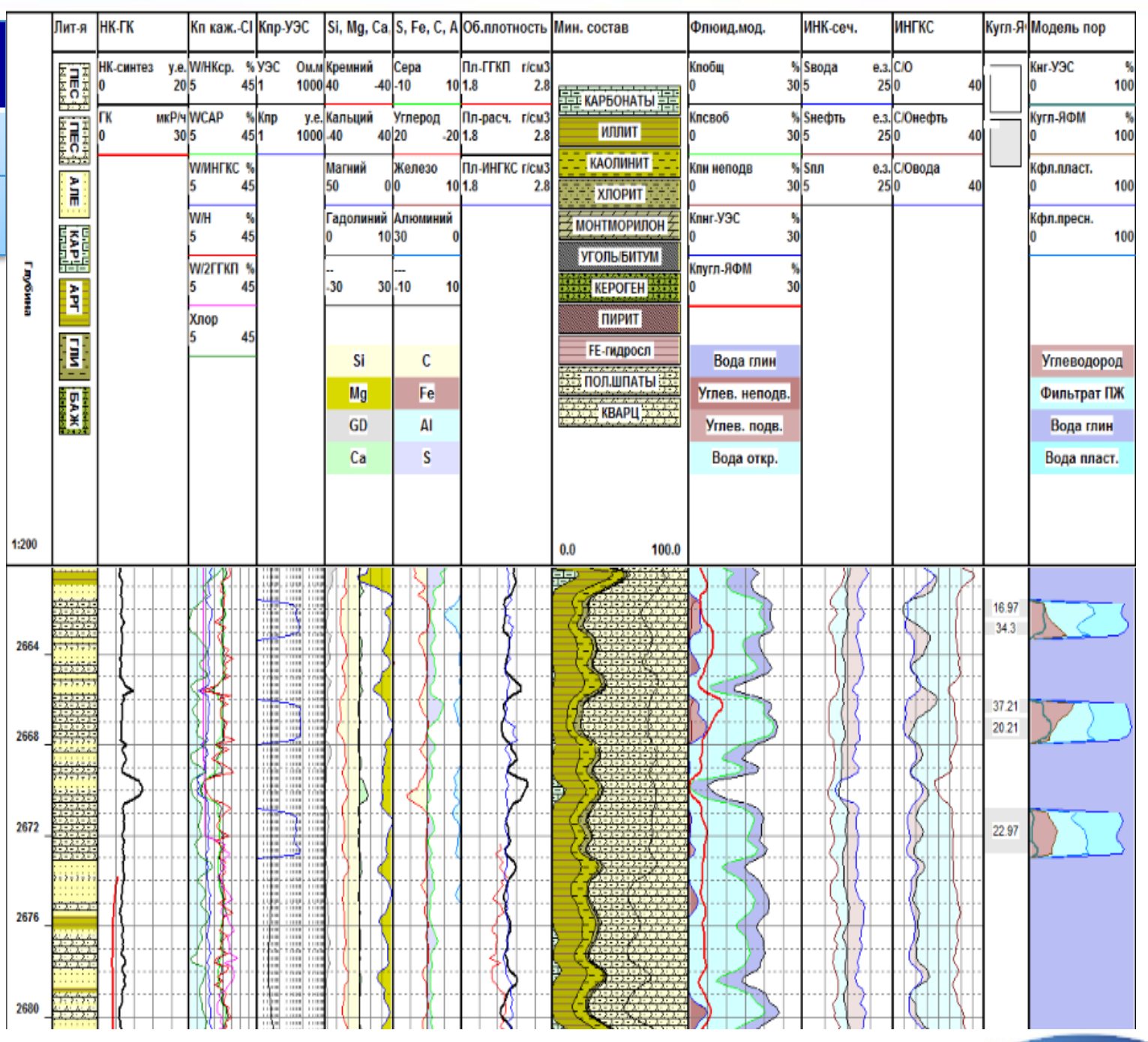




\section{ОПИ СМИС-172-Б}

\section{Сопоставление результатов интерпретации с комплексом МЕГА-3}

ОПИ после доработки

- Водородосодержание по ИНГКС хорошо согласуется водородосодержанием ТПГ по всему представленному разрезу.

- Кривая плотности по ИНГКС имеет достаточно низкую дифференциацию и слабо коррелируется с показаниями плотности ТПГ.

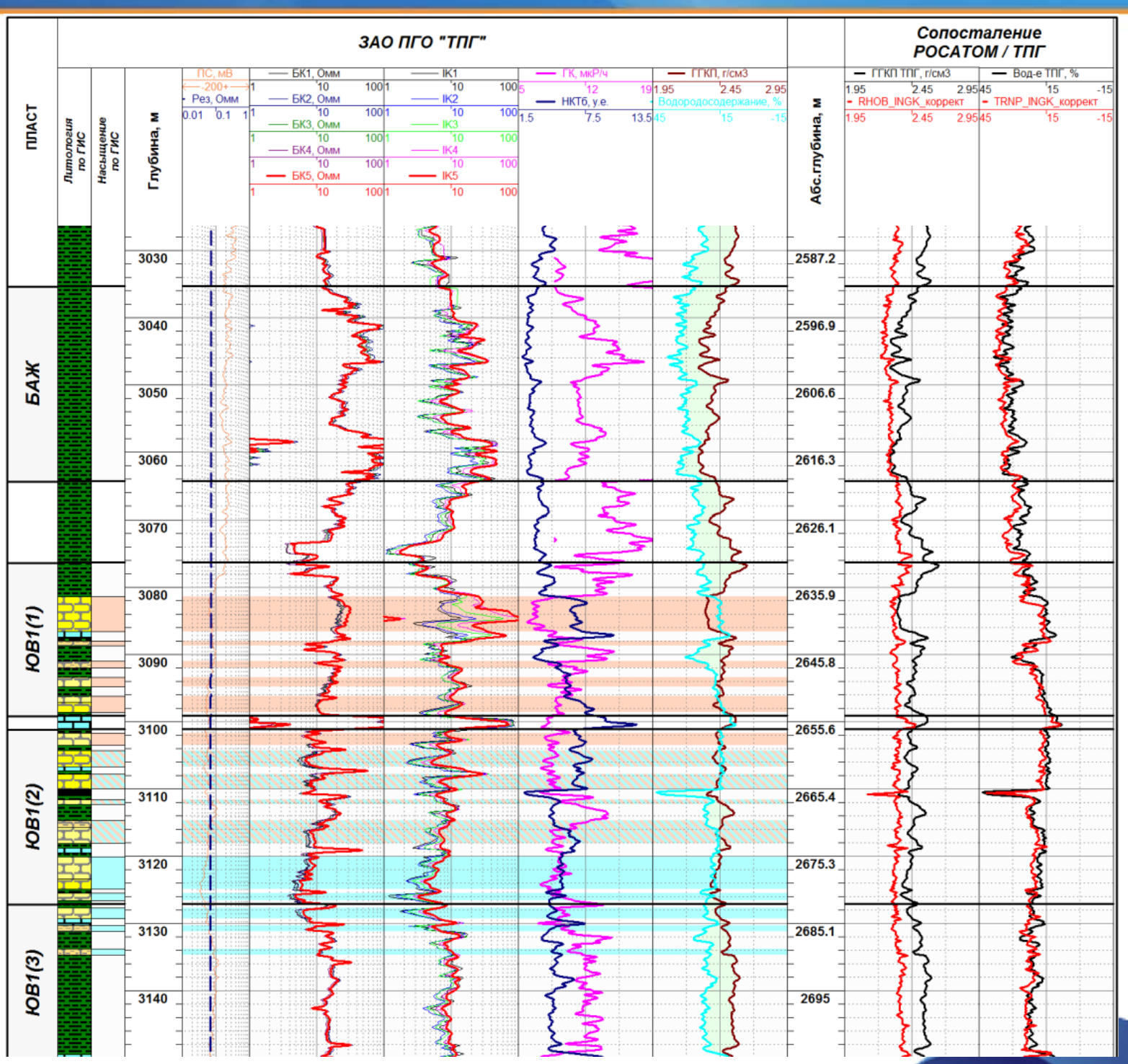

17 


\section{Модуль ИНК для определения лористости и плотности в процессе бурения}

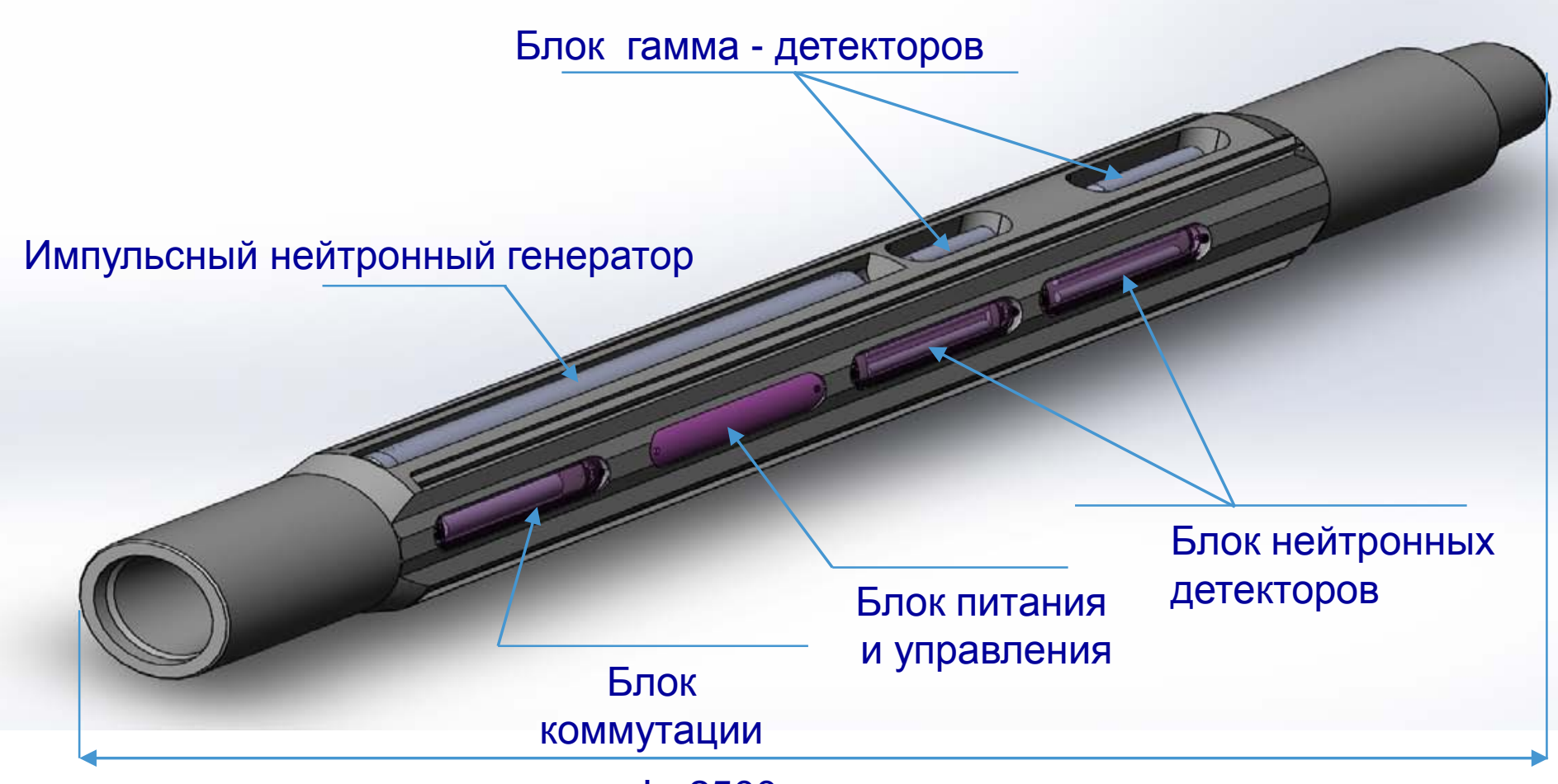

$\mathrm{L}=2500 \mathrm{MM}$.

Новый модуль ИНК позволит:

- увеличить ресурс работы комплекса

- Уменьшить длину компоновки в процессе бурения

- Увеличить точность определения пористости и плотности г.п. 


\section{Автономная аппаратура}

\section{для каротажа на бурильных трубах \\ СМИС-102-А}




\section{Автономная аппаратура для каротажа на бурильных трубах СМИС-102-A}

ВЭМК3-102-А: модуль высокочастотного электромагнитного каротажного зондирования

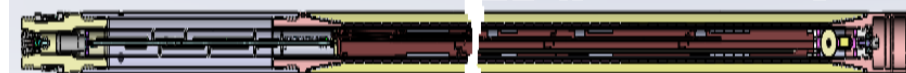

Модуль ИНгК-102-А: модуль импульсного нейтронного гамма-спектрометрического каротажа

\section{4.}

ИНКЛ-102-А: модуль инклинометра

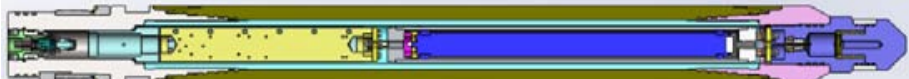

МРГК-102-А: модуль резистивиметра и гамма-канала

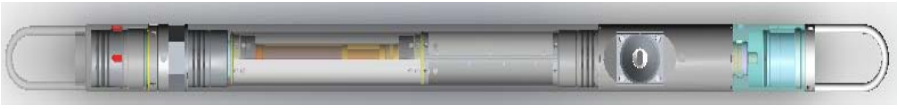

МПП-102-А: модуль памяти и питания

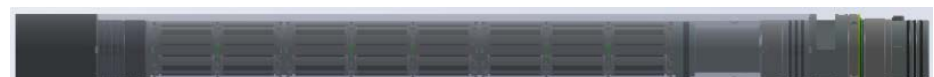

БК-102-А: модуль бокового каротажа

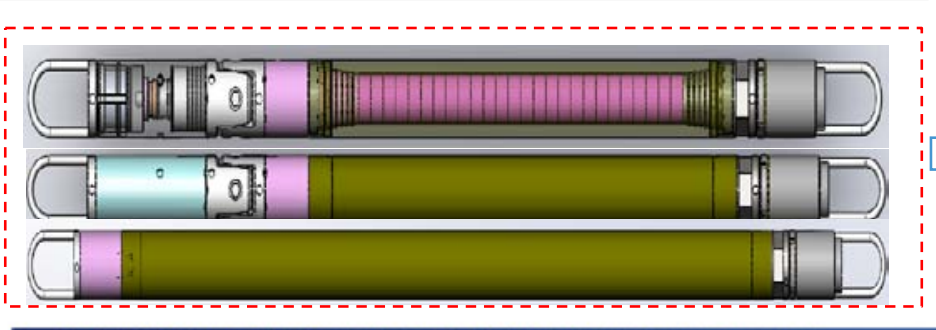

ВСЕРОССИИСКИИ НИИ АВТОМАТИКИ им. Н.Л.Духова
Измерение УЭС с помощью 9

разноглубинных электромагнитных зондов

- Элементный состав;

- Минералогический состав;

- Плотность;

- Пористость

- Зенитный угол;

- Азимутальный угол

- Естественная гамма-активность;

- Сопротивление бурового раствора

-Обеспечение питанием комплекса в течении 304

- Сохранение данных в память

2 разноглубинных зонда УЭС 


\section{Общие эксплуатационные характеристики комплекса CMИC-102-A}

\section{Назначение:}

Комплекс предназначен для исследования открытого ствола скважин диаметром от 120 до 245 мм, бурящихся на нефть и газ

\section{Комплекс позволяет измерять:}

\section{Плотность}

Пористость

Насыщенность

Элементный состав

Естественную гамма-активность горных пород Удельное электрическое сопротивление (УЭС) пласта

$\checkmark$ Азимутальный, зенитный угол, угол отклонителя

\section{Особенности:}

Применение управляемого импульсного нейтронного

генератора вместо ампульных источников

Определение компонентного состава порового флюида независимо от минерализации пластовых вод

\section{Технические характеристики}

\begin{tabular}{|c|c|}
\hline Диаметр исследуемых скважин, мм & $120-245$ \\
\hline Рабочая температура, ${ }^{\circ} \mathrm{C}$ & 85 \\
\hline Рабочее давление, МПа & 80 \\
\hline Диаметр, мм & 102 \\
\hline Длина, м & $\approx 18$ \\
\hline Macca, кг & 500 \\
\hline Работа в автономном режиме, час & 30 \\
\hline Измеряемый параметр: & Диапазон \\
\hline УЭС, ОМ*M & $0,2-20000$ \\
\hline$Г К, ~ м к Р / 4 ~$ & $1-250$ \\
\hline Зенитный угол, о & $0-120$ \\
\hline Азимут, ${ }^{\circ}$ & $0-360$ \\
\hline Пористость, \% & $1-40$ \\
\hline Плотность, г/см³ & $1-3$ \\
\hline
\end{tabular}




\section{Пример проведения ОПИ аппаратуры СМИС-102-А Волго-Уральский регион}

\begin{tabular}{|l|l|}
\hline \multicolumn{2}{|c|}{ Параметры скважины } \\
\hline Объект & Ветлянское м-ие \\
\hline Условия проведения работ & Открытый ствол \\
\hline Диаметр скважины, мм & 216 \\
\hline Интервал исследования, м & XX88,2-XX91; XX95,6-XX97,4 \\
\hline Тип жидкости в скважине & $\begin{array}{l}\text { Гипсо-известковый с } \\
\text { полимерными добавками }\end{array}$ \\
\hline Удельный вес жидкости, г/см & 1.2 \\
\hline
\end{tabular}

\begin{tabular}{|l|l|}
\hline \multicolumn{2}{|c|}{ Результаты интерпретации СМИС-102-А } \\
\hline $\begin{array}{l}\text { Модель твердой } \\
\text { составляющей }\end{array}$ & $\begin{array}{l}\text { песчаник, алевролит, аргиллит, } \\
\text { карбонаты }\end{array}$ \\
\hline $\begin{array}{l}\text { Модель } \\
\text { минерального } \\
\text { состава }\end{array}$ & $\begin{array}{l}\text { Кварц, полевые шпаты, кальцит, } \\
\text { доломит, гипс, ангидрит, битум, } \\
\text { гидрослюда, каолинит }\end{array}$ \\
\hline $\begin{array}{l}\text { Флюидальная } \\
\text { модель }\end{array}$ & $\begin{array}{l}\text { Улеводороды, вода глин, вода } \\
\text { пластовая, фильтрат Пж }\end{array}$ \\
\hline
\end{tabular}

Интервал xх88,2-хx91,0 м.:

нефтенасыщен; Кп=8\%; Кн=30\%.

Интервал хx95,6-хx97,4 м.:

нефтенасыщен; Кп=8\%; Кн=32\%.

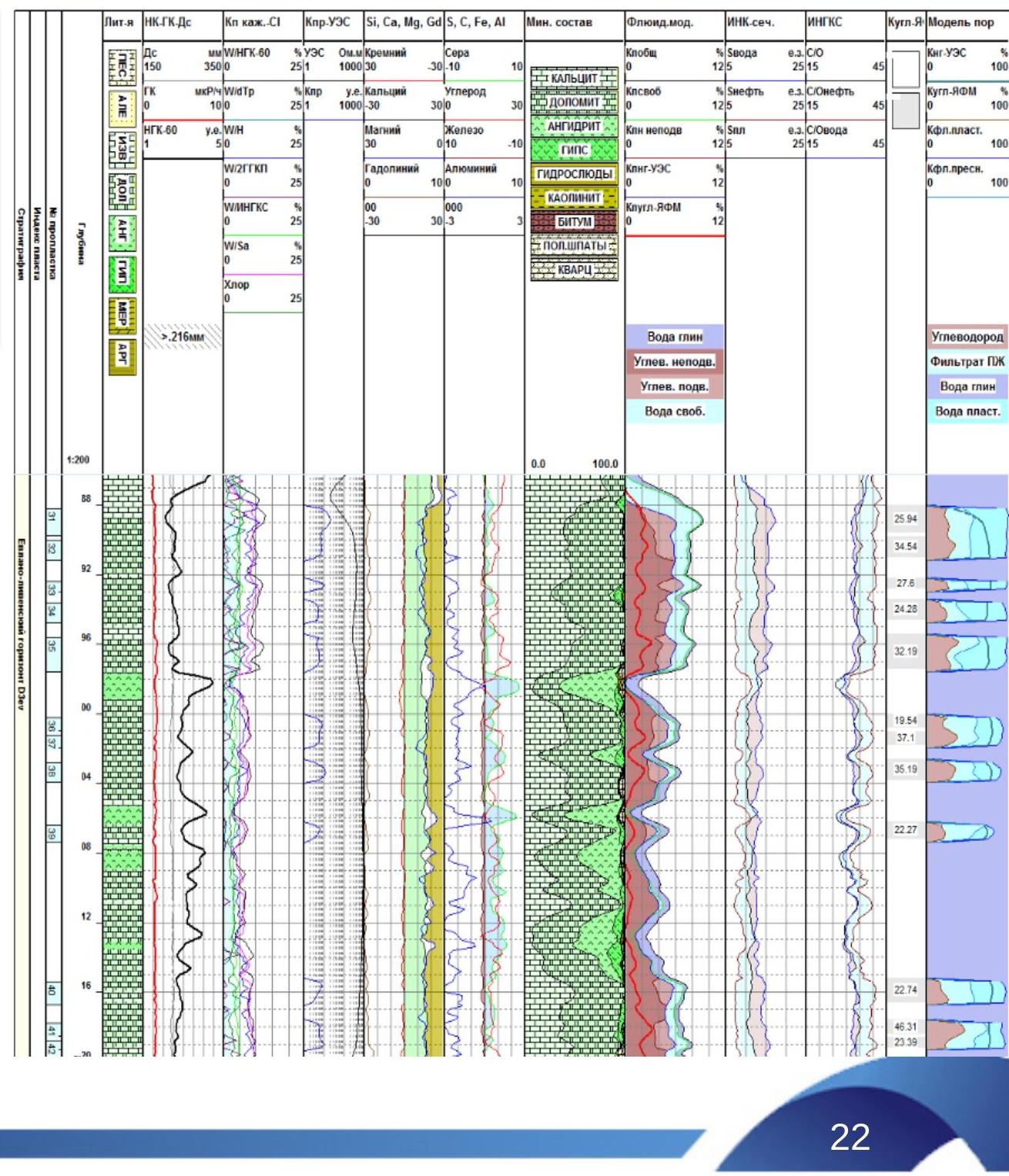


Сравнительный анализ результатов ГИС каротажа на трубах АМК «Горизонт» и каротажа на трубах СМИС-102-А

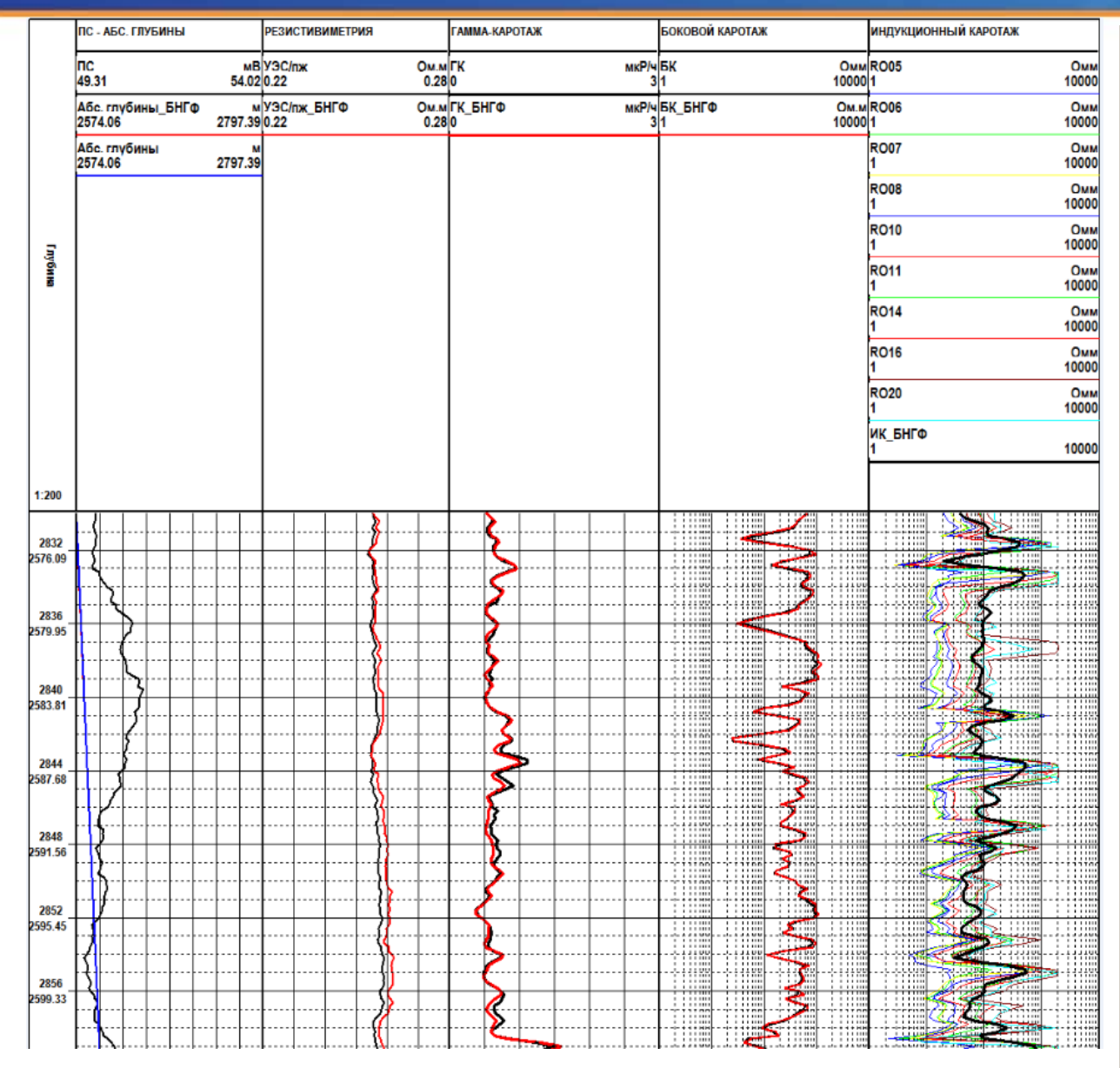

В результате сопоставления методов ГК, БК, ИК СМИС-102-А с АМК Горизонт наблюдается хорошая сходимость методов.

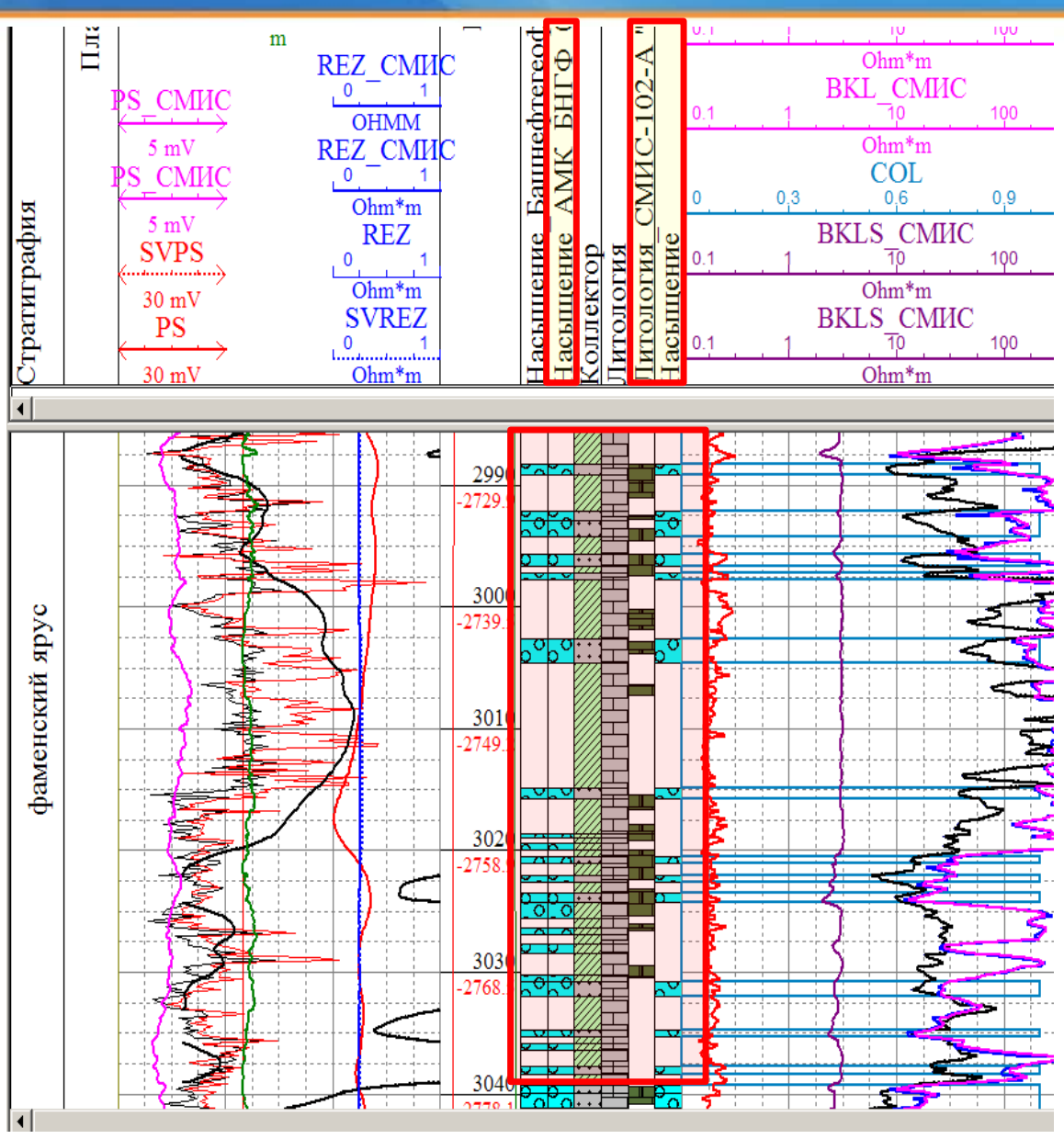

Заключение 000 «СамараНИПИнефть»: «Пористости по обоим каротажам близки, примерно 1\% абсолютная разница. 


\section{Итоги проведения ОПИ комплексом СМИС-102-А}

\section{Рекомендации АО «Самаранефтегаз»}

1. Включить в модульную сборку прибора СМИС-102-А модуль профилемера (АКП) для полноценного расчленения разреза и поиска коллекторов.

2. Предоставить алгоритмы и методики расчёта параметров по комплексу СМИС-102-А.
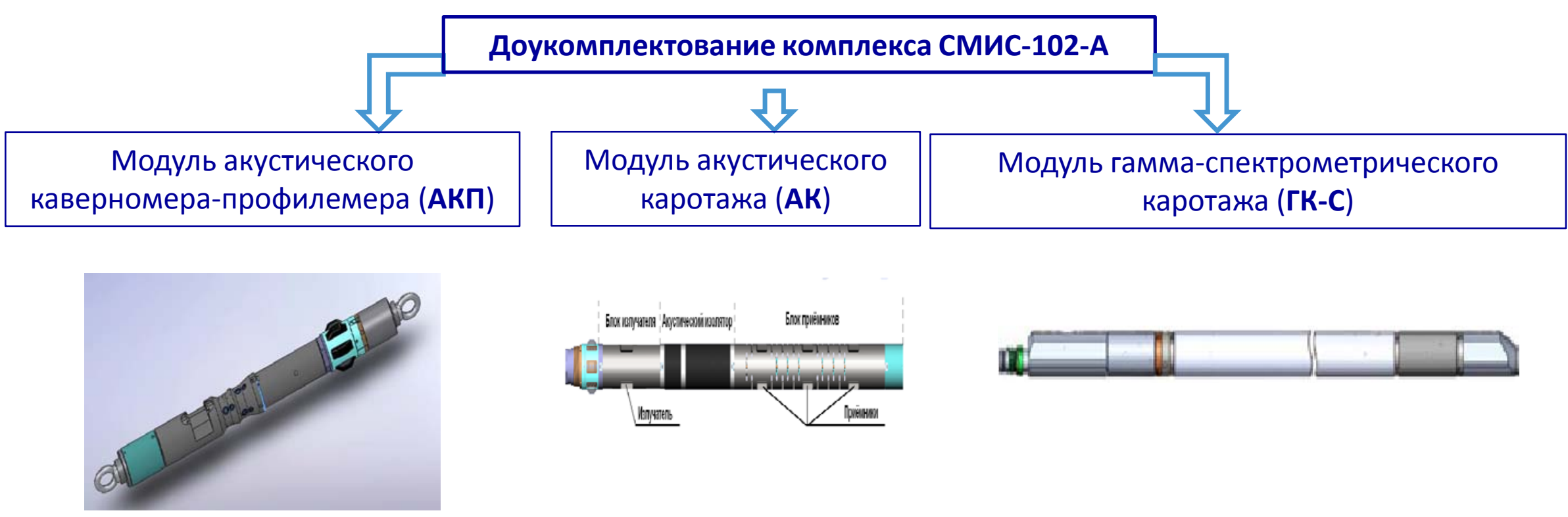

Доукомплектование комплекса СМИС-102-А завершено в 4кв. 2018г. 


\section{Аппаратура импульсного}

\section{нейтрон-нейтронного каротажа}

\section{АИНК-43П}




\section{Физические основы метода ИННК}

Метод ИНнК основан на облучении горной породы быстрыми нейтронами (14 МэВ) и регистрации тепловых нейтронов, возникающих в результате взаимодействия нейтронов с ядрами горных пород.

Принцип работы аппаратуры ИННК

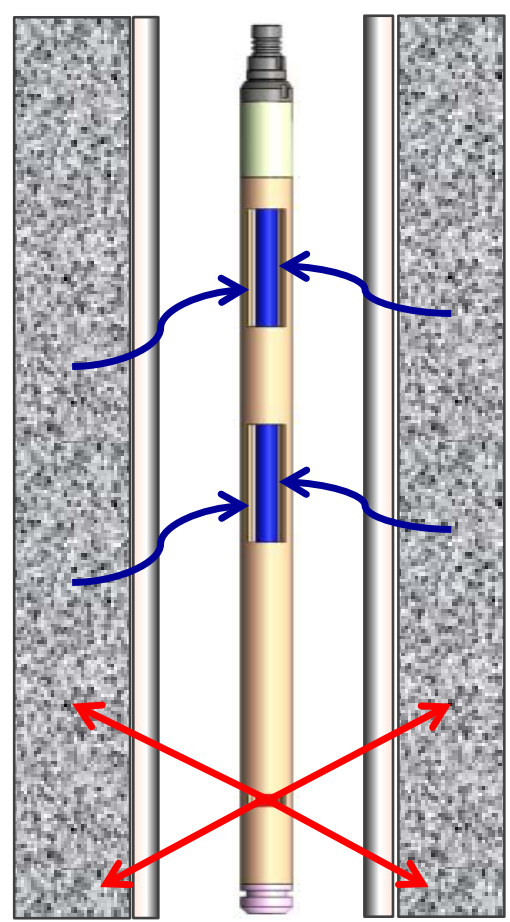

$\mathbf{N}_{\text {тепловые }}$ $(0,025$ эВ)

$\mathrm{N}_{\text {быстрые }}$ (14 MэB)
Программа регистрации данных ИННК

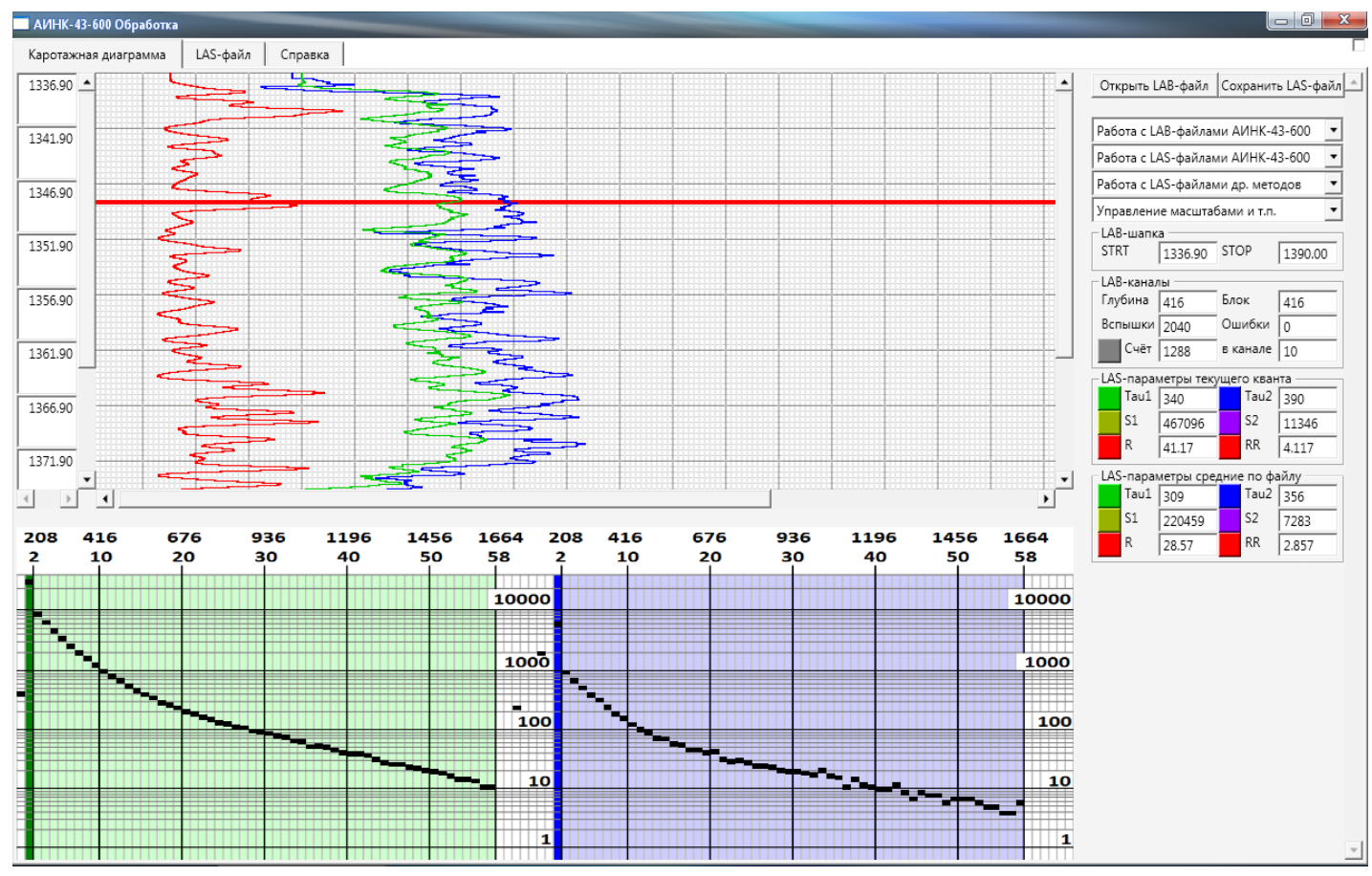




\section{Аппаратура импульсного нейтронного каротажа АИНК-43П}

Блок

регucmpamopa

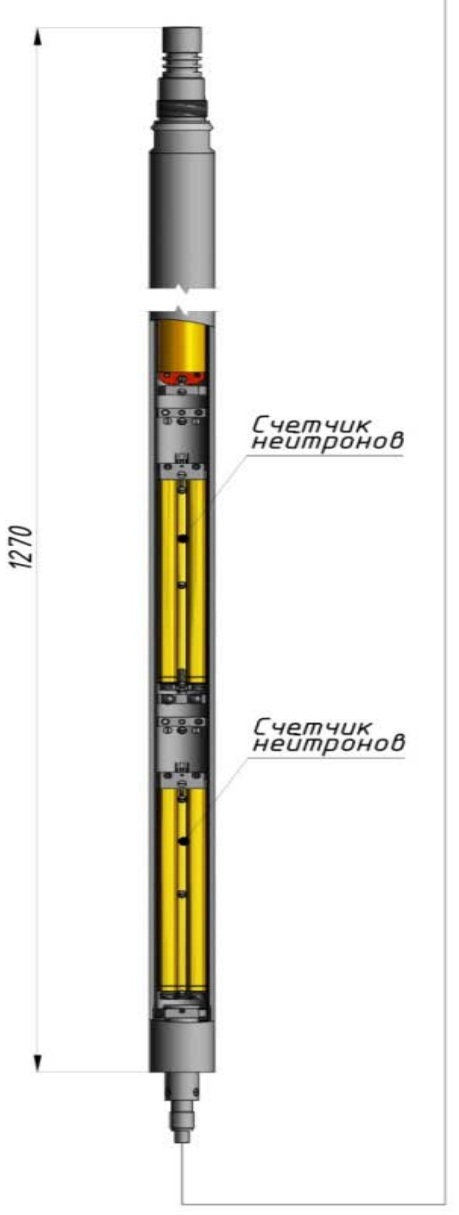

Блок

чзлучателя

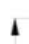

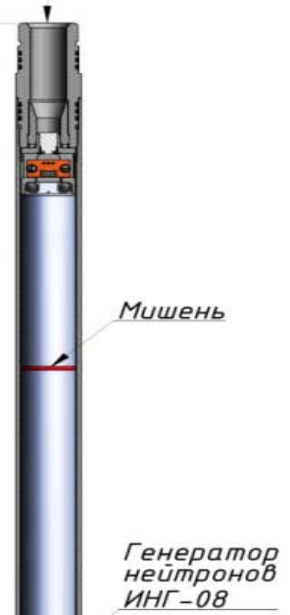

\section{НАЗНАЧЕНИЕ:}

Проведение исследований в обсаженных $и$ необсаженных нефтегазовых скважин, в том числе через НКТ, методом ИННК по тепловым нейтронам.

\section{РЕШАЕМЫЕ ЗАДАЧИ:}

- Насыщенность (Кг, Кн)

- Пористость (Кп)

- Положения и перемещения флюидальных контактов

- Обводненность пластов

\section{ОСОБЕННОСТИ:}

- Возможность регулировки выхода нейтронного потока

- Детекторы тепловых нейтронов с высоким временным разрешением на основе кассеты $\mathrm{He}_{3}$ счетчиков 


\section{Сопоставление АИНК-43-50 и АИНК-43П}

\begin{tabular}{|c|c|c|}
\hline Параметр & АИНК-43-50 & АИНК-43П \\
\hline Диаметр, мм & 43 & 43 \\
\hline Длина, мм & 3000 & 2790 \\
\hline Рабочая температура, ${ }^{\circ} \mathrm{C}$ & $120 / 150$ & $120 / 150$ \\
\hline Тип нейтронного генератора & ИНГ-10-20-120 (150) & ИНГ-08 \\
\hline Тип нейтронной трубки & Вакуумная (ВНТ) & Газонаполненная (ГНТ) \\
\hline Рабочая частота, Гц & 20 & 600 \\
\hline $\begin{array}{l}\text { Гарантированный ресурс } \\
\text { генератора, } 4\end{array}$ & 150 & 300 \\
\hline Мертвое время детекторов, мкс & 2 & 0.8 \\
\hline Определяемые параметры пластов & $\Sigma a$ & $\Sigma \mathrm{a}, \mathrm{Kп} \mathrm{(ГК,} \mathrm{ЛМ)}$ \\
\hline
\end{tabular}

Новая аппаратура реализует функции двух методов каротажа:

- импульсный нейтронный каротаж для определения $\Sigma$ a

- нейтронный каротаж для определения коэффициента водонасыщенной пористости 


\section{ОПИ аппаратуры АИНК-43П}

Цель: Выявление обводнения пластов разрабатываемого объекта

\section{Условия измерения:}

диаметр скважины 245 мм, колонна ф 168 мм.

\section{Характеристика исследуемых пластов:}

Интервалы исследований включают в себя четыре терригенных пласта, находящихся в разработке. По каротажу открытого ствола все пласты содержали нефть.

\section{Заключение:}

По результатам ИННК два верхних пласта полностью обводнены

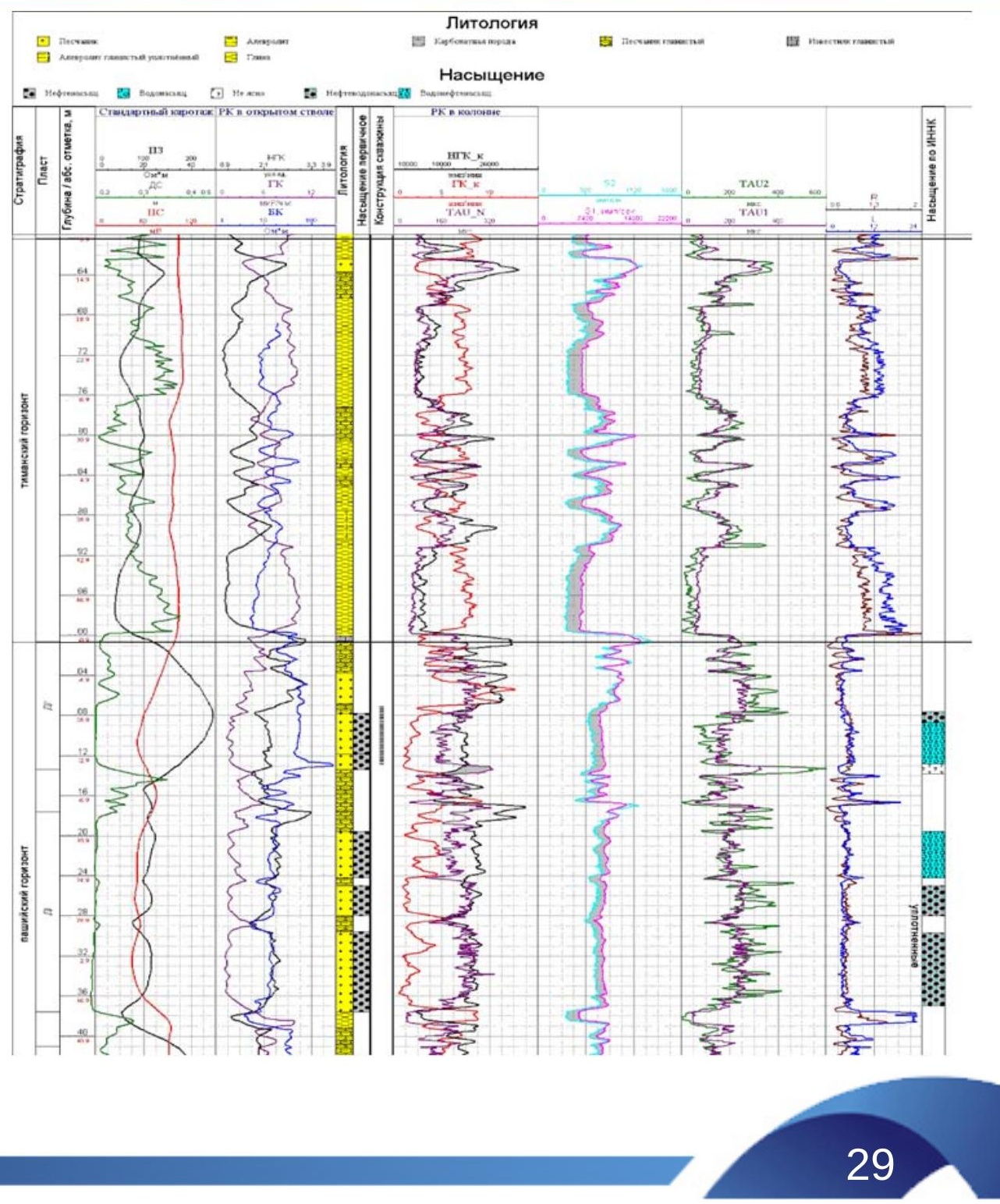




\section{Опытно-промышленные испытания АИНК-43П}

Комплекс АИНК-43П позволяет определять: (обсаженный ствол)

$>$ Нейтронная пористость горных пород

$>$ текущую нефтенасыщенность

Повышает:

уровень радиационной безопасности

$>$ Достоверность оценки пористости и нефтенасыщенности

Для повышения радиационной безопасности и повышения информационных возможностей импульсного нейтронного каротажа рекомендуется замена аппаратуры радиоактивного каротажа с изотопным источником на аппаратуру АИНК-43П. 


\section{Аппаратура импульсного нейтрон нейтронного каротажа АИНК-34}




\section{Аппаратура нейтронного каротажа АИНК-34}

AИHK-34

Телеметрия

Генератор

ИHГ $-11-20-150$

Мишень

ฟิ

ç⿻上丨)

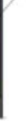

Cuemunk
Heumporob
НАЗНАЧЕНИЕ: исследОВание действующих нефтяных и газовых скважин.

\section{Технические характеристики}

Макроскопическое сечение поглощения
тепловых нейтронов в пласте

Тип нейтронного генератора

ИНГ-11-20-150 (на вакуумной нейтронной трубке)

Потребляемая мощность

Количество измерительных зондов

$30 \mathrm{BT}$

Температура окр. среды

2

Длина

Диаметр

$150^{\circ} \mathrm{C}$

$2500 \mathrm{MM}$

$34 \mathrm{MM}$

\section{ОСОБЕННОСТИ:}

- малый диаметр и малая длина скважинного прибора позволяют проводить исследования межтрубного пространства через НКТ без глушения и при высоких давлениях на устье скважин. 


\section{ОПИ Аппаратуры АИНК-34}

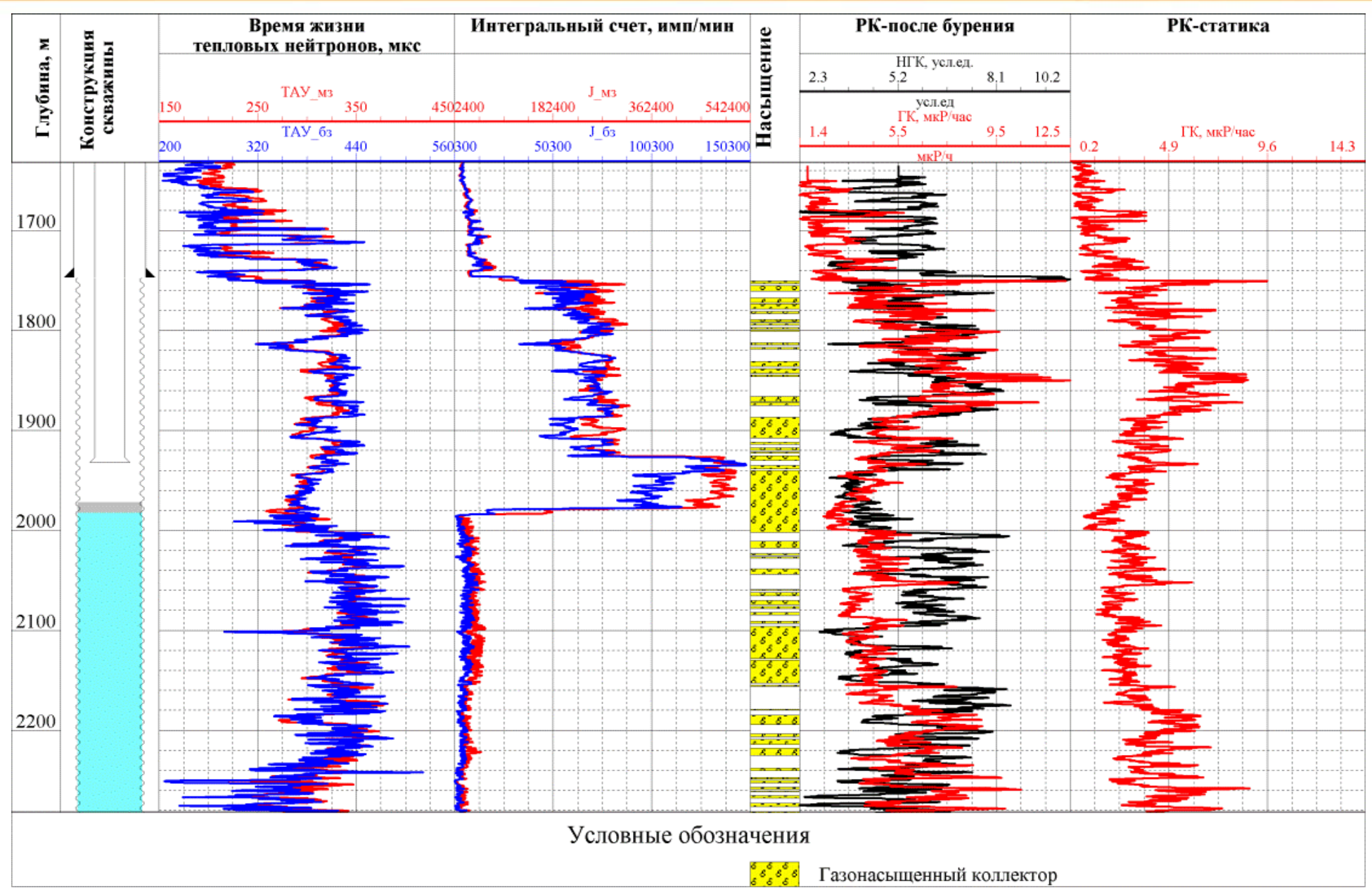

- Смена заполнения скважины с воды на газ на уровне 1970 м практически не влияет на значение параметра ТАУ, что позволяет исследовать свойства газонасыщения пласта независимо от заполнения скважины. 


\section{Спасибо за внимание!}

Контакты:

E-mail: bogolubov@vniia.ru 